\title{
Focus on Modernization \& Improvements in Dall(Pulses) Mills
}

\author{
Dr. Sanjay K. Patil, \\ Associate professor \\ College of Engg. \& Technology, Babhulgaon, Akola. \\ (M.S.) India-444104.
}

\begin{abstract}
Dall(pulses) Milling is one of the major foods processing industry in country. In Many states like Maharashtra and Madhya Pradesh in industrial area majority of units are Dall(pulses) mills. Millers want to improve quality of dall(pulses) to remain competitive in the market. But it is observed that very few of them are taking concrete steps in improving the old methods of working and adopting newer technologies. Improved methods of working and adopting newer technologies helps in improving dall(pulses) mill working to make operations simpler, safer, efficient, reliable ultimately improving quality and yield of final output. As a technocrat I studied the need of modernization in dall(pulses) mill, and took active participation in discussion with millers and millers showed keen interest to study the present systems and methods adopted in majority of dall(pulses) mills and what improvements can be implemented in Dall(pulses)(Pulses) mills. After through study author suggested the need of automation and modernization and discussed systems and methods that's needs to be implemented.
\end{abstract}

\section{INTRODUCTION}

In Indian dietary regime, pulses occupies an important place since the majority of Indians are vegetarian, they depend largely on grain legumes (pulses) for their dietary protein. Pulses contribute major protein of lysine in the vegetarian diet.

They are also good source of vitamins like thiamine, niacin, riboflavin and much needed iron. Therefore its quality availability to a common man is a major challenge. Milling of pulses means removal of the outer husk and splitting the grain into two equal halves. De hulling of pulses refers to first loosening the seed coat from cotyledons by pretreatment \& secondly, removal of seed coat and then splitting the grain in two cotyledons. Obtaining the maximum dall(pulses) of good quality with less chipped off edges, broken and powder per unit of white grains is called hulling quality.

Dall(pulses) Milling is one of the major foods processing industry in country. In Many states like Maharashtra and Madhya Pradesh in industrial area majority of units are Dall(pulses) mills. Millers want to improve quality of dall(pulses) to remain competitive in the market. But it is observed that very few of them are taking concrete steps in improving the old methods of working and adopting newer technologies. Improved methods of working and adopting newer technologies helps in improving dall(pulses) mill working to make operations simpler, safer, efficient, reliable ultimately improving quality and yield of final output. As a technocrat I studied the need of modernization in dall(pulses) mill, and took active participation in discussion with millers and millers showed keen interest to study the present systems and methods adopted in majority of dall(pulses) mills and what improvements can be implemented in Dall(pulses)(Pulses) mills.

\section{METHODOLOGY}

After studying critically we have come out with our views regarding Automation \& modernization in dall(pulses) mill.

$>\quad$ Presently traditional way of layout \& machinery set up is adopted in majority of mills. Dall(pulses) mill contractors have fixed set framework for installation of machinery. They have blue print of traditional layout in their mind as they are doing same thing years together. But now in this modern era we are lucky that we have latest designing tools available in market. Presently new commercial (CAD) softwares are available to design layout of dall(pulses) mill. By using these soft wares we can specify positions of machines, equipment \& facilities. 3-D modeling gives the feel of actual factory on computer screen. Now a days many mills are designed for multistoried vertical layout in which machines, equipment $\&$ other facilities are installed at different floors. Here 3-D modeling is beneficial, as it can show set up of machines at every floor. One can get information of heights of machines; drive system arrangement, relative distances, and slope of ducting \& relative positioning of the equipment on one floor with the equipment on other floor. Any changes on computer screen are possible while designing. Actual dimensions of machines in 3-D view will give feel of virtual reality of factory on screen. It is very easy to get different views once 3-D model is ready. Drawing-1 is showed to give feel of 3-D model of multistoried dall(pulses) mill with machinery set up at different floors. 


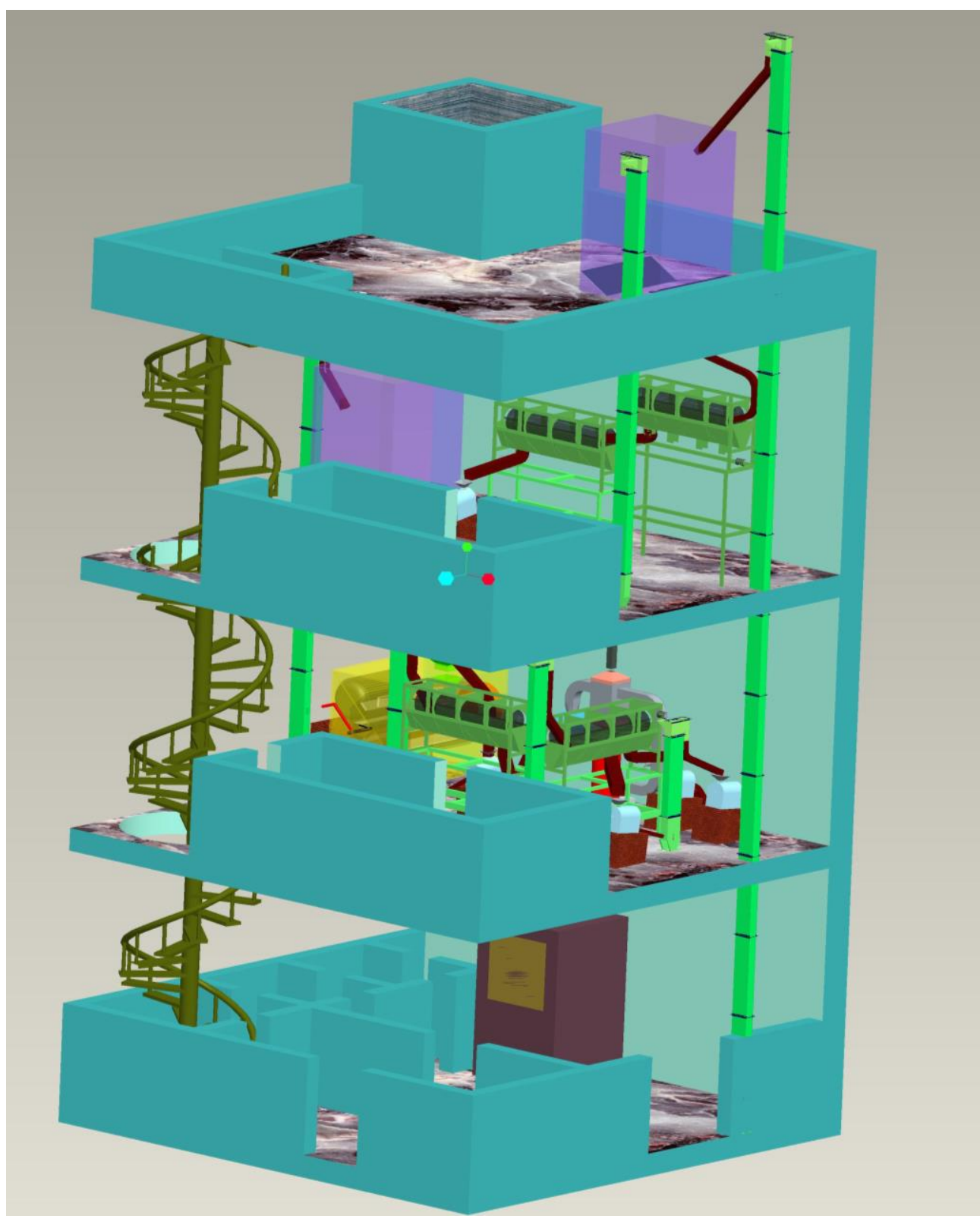

DRAWING-1 showing 3-d model of multistoried dall(pulses) mill

There are many advantages of new type of multistoried vertical layout like reduction in handling of material; sun drying is possible at building top. This type of layout provides good height gradient for gravity feeding of material in process. Avoids congestion in process and facilitates simpler arrangement of drive system. Handling of material has become simpler \& is not labor intensive as in horizontal layout especially in case of sun drying.

The provision for set up of color sorter machines can be easily made in this type of layout.

Computer controlled total automation is possible in dall(pulses) mill if layout \& all systems in the dall(pulses) mills are designed keeping in view to go for complete automation. In automated plant it is easy to carry out all the activities in controlled way as per set parameters.

Some important systems required for automation in dall(pulses) mill are discussed

below,
Arrangement of centralized control system to control all activities through operators control desk. Programmable logic controller can be used for controlling all the activities from control desk.

$>$ Moisture meter with signaling facility to give information of moisture content in material to control panel. It should be supported with auto flow sampler to take sample of pulses in process from various points like drier, first feeding point and many other critical points.

$>$ Special design improvement in drier for auto leveling, mixing \& unloading

of material. Hydraulically operated lifting system can be tried in drier for

Unloading \& need provision of auto temperature controlling system.

$>$ Need of adopting concept of machine vision to check quality to see the percentage impurities in raw grain as 
well as checking quality of milling like breakages in dall(pulses) at various stages. On the basis this information various parameters like flow rate of material feed to roll, speed of roll, distance between dall(pulses) mill roll \& outer circular screen top half portion can be controlled automatically.

- Facility in computer to see parameters like temperature of drier, time of heating, no. of batches \& many other on screen as per your priority. Hence there is a need to install monitoring, feedback \& safety systems in plant.

$>$ In dall(pulses) mills common problem that is faced regularly is jamming of bucket elevator at the time of power failure. This can be sorted out by providing auto-operated shutter at the inlet-feeding chute. The inlet feed shutter will immediately close \& stop feeding of material to bucket elevator. The pneumatically operated cylinder system can be a better option to shut the flap at the time of power failure.

$>$ Online installation of Auto weighing filling \& packing machines to make this labour intensive operation very accurate and easy.

$>$ Need to install auto-controlled system for applying oil to pulses in precise quantity.

There are some areas where as per our views some improvements are needed in dall(pulses) mills having conventional set up.Pulses miller accepted this suggestions and most of the millers implemented the suggestions listed below,

$>$ There is need of controlling moisture level of material in process at various stages to get uniformity in output quality. Workers should be trained to use advance electronic moisture meter. Moisture has a great impact on final quality of pulses.

$>$ Need the provision of feed shutter at inlet chute of bucket elevator for immediately stopping the feeding of material. This help to avoid jamming at the time of power failure as discussed above.

$>$ The capacity of bucket elevators to be set as per requirement. The speed and conveying capacity are critical points that need to be taken care. Excessive belt speed can increase percentage of breakages \& cut in pulses due to high impact.

$>$ There are various types of driers used in dall(pulses) mills. But majority of driers used are bed type in which the $2.5 \mathrm{ft}$. to $3 \mathrm{ft}$ depth of pulses is maintained. In these driers there is no arrangement to turn pulses upside down for uniform moisture removal. There is need of dryer designed with auto mixing arrangement to turn pulses upside down for uniform removal of moisture.

$>$ There is urgent need to set maintenance schedule to avoid breakdown. The procedure must be set for regular \& preventive maintenance. It is observed that presently majority of dall(pulses) mills don't have any schedule for maintenance. This results in frequent breakdown \& finally affecting productivity of mill.

$>$ Need to provide protective guards to all belt pulley drive systems and other hazardous areas e.g. screw conveyors needs to be covered from top with wire mesh to make the system safer. Workers should be trained to follow safer methods of working.

$>$ Presently in many dall(pulses) mills dust collection systems with bag filter arrangement are provided for settling of dust are installed. In these systems bags are to be cleaned manually. It is very tedious job for workers to clean the bags periodically. Failure in timely cleaning the bags of filters reduces the efficiency of system. There is need of efficient auto cleaned bag filter dust collection system.

$>$ In majority of dall(pulses) mills the circular rotary type screen graders are used for gradation of raw material \& pulses in process. Chocking of screen is common problem. Choking of reduces the cleaning efficiency. There is a need of inbuilt screen cleaning system such as brush cleaning system, air jet cleaning system etc.

$>$ Sometimes millers directly sellout green gram seed (moong) in market after grading \& polishing without going for milling. While polishing dust on the surface of green gram is removed but the liberated dust get settled there only giving dull surface to green gram seed. It is necessary to install supporting system to remove dust effectively from polishing chamber. The systems like powerful air suction can be tried for dust removal.

\section{RESULT AND DISCUSSION}

The systems and methods suggested in the article has been implemented by some of the millers and are benefitted as these suggestions has improved the quality of dall pulses. As all the parameters of raw material is controlled before it enters into process and proper setting of working parameters of and adoption of proper systems and machines during process, the quality and quantity output is drastically enhanced. The cut seed percentage is reduces by $75 \%$, loss due to powder formation reduces by $80 \%$, easy segregation of good dall pulses and waste removed from it during the process. The maintenance and downtime in mill drastically reduces nearly $90 \%$ down time is reduced. Requirement of skilled labor is reduced.

\section{CONCLUSION}

There is always a scope for development $\&$ up gradation in any system. Our aim is to show roadmap for modernization $\&$ improvements in dall(pulses) mills.

It is very good sign that every mill owner wants to improvise the present systems. That is the reason dall(pulses) millers have installed color sorters, the machine based on latest technique of sorting pulses on the basis of colors. This initiative of dall(pulses) mill owners forced us to contribute something on this subject through this article. And by adoption of this systems and methods suggested in this article the pulses millers are and will be benefited in terms of increase in pulses quality and production quality. This is need of Indian Pulses millers. 